\title{
SPATIAL PREFIXES IN DARGI (EAST CAUCASIAN)*
}

\author{
HELMA VAN DEN BERG
}

\begin{abstract}
This article explores the morphological nature of what are traditionally called spatial prefixes in the East Caucasian language Dargi. Having developed historically from adverbs, the prefixes are now completely integrated into the verb's morphology, syntax and semantics. Instead of regarding verbs derived with these spatial prefixes as prefixed stems on a synchronic level as well, the alternative proposed here is to consider them bipartite stems. This also fits a recent proposal to regard bipartite stems as a feature of the East Caucasian language family as a whole.
\end{abstract}

\section{Introduction}

This article explores the morphological nature of what are traditionally called spatial prefixes in the East Caucasian language Dargi. Having developed historically from adverbs, the prefixes are now completely integrated into the verb's morphology, syntax and semantics. Section 2 provides a description of the prefixes on the basis of the literature, and gives an account of their historical development. On the basis of new data collected during fieldwork, the syntagmatic, paradigmatic and semantic properties of the prefixes will be analyzed in section 3. Instead of regarding verbs derived with these spatial prefixes as prefixed stems on a synchronic level as well, the alternative that will be proposed here, is to consider them bipartite stems. This also fits a

* This paper was presented at the 10th Morphology Meeting in Budapest/Szentendre, May 9th-12th 2002. I would like to thank the participants of this conference for their questions and remarks. I express my gratitude to Bernard Comrie, Grev Corbett, Marianne Mithun, Eva Schultze-Berndt, Lea Brown, and the anonymous reviewer for helpful comments on a draft version of this paper. I am grateful to Scott DeLancey for helping me to trace some of his papers, and to Johanna Nichols for discussing bipartite stems in a broader East Caucasian perspective with me. I am indebted to the Dargi speakers in the village of Akusha (Daghestan), and in particular to Mrs. Hadizhat Omarova, for their time and patience while teaching me their language. Financial support for the fieldwork from the Netherlands Organization for Scientific Research (NWO) and the Max Planck Society is gratefully acknowledged.

1216-8076/03/\$20.00 (c) 2003 Akadémiai Kiadó, Budapest 
recent proposal to regard bipartite stems as a feature of the East Caucasian language family as a whole, which will be discussed in section 4 .

\subsection{Dargi}

Dargi is an East Caucasian language spoken by approximately 366,000 speakers in the Republic Daghestan (Russian Federation). It is currently considered a separate branch within East Caucasian, on a par with the Nakh, Avar-Andic, Tsezic, Lak and Lezgic languages (Nikolayev-Starostin 1994). Dargi has wide dialect variety and some of the geographically more peripheral dialects are often considered separate languages. The written standard is based on the Akusha dialect. Data for this study come from Akusha Dargi and were collected during on-site fieldwork. Dargi has fairly consistent head-final word order in the clause and the noun phrase. It has rich suffixation on nouns and verbs, a well-developed case inventory and absolutive/ergative case-marking.

\subsection{Dargi prefixes}

There are three types of verbal prefixes in Dargi (van den Berg 2001, 32):

a. gender prefix: Dargi has three genders in the singular (masculine, feminine, neuter) and two gender distinctions in the plural.

Table 1

Gender affixes in Akusha Dargi

\begin{tabular}{|l|c|c|c|}
\hline \multirow{2}{*}{\multicolumn{2}{|c|}{ SINGULAR }} & \multicolumn{2}{|c|}{ PLURAL } \\
\cline { 3 - 4 } \multicolumn{2}{|c|}{} & 1,2 & 3 \\
\hline \hline $\mathrm{M}$ & $w$ & \multirow{2}{*}{$d-,-d-,-r$} & $b$ \\
\hline $\mathrm{F}$ & $r$ & \multicolumn{2}{|c|}{$d-,-d-,-r$} \\
\hline $\mathrm{N}$ & $b$ & \multicolumn{2}{|c|}{$d$} \\
\hline
\end{tabular}

Verbs agree with their $\mathrm{S} / \mathrm{P}$ in gender, thus showing ergative cross-reference of arguments e.g.,
(1) (a) w-ak'-ib m-come-aor(3)
(b) r-ak'-ib f-come-aor $(3)$
'He came.'
'She came.' 


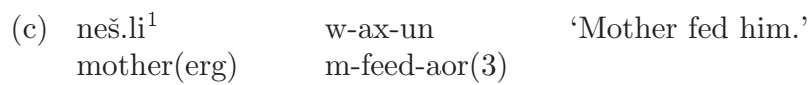

b. negation prefixes: there are two prefixes for negation, negative $\hbar e-$ and prohibitive $m a_{-}$. The latter is used in the negative imperative and negative optative, whereas $\hbar e$ - is used in all other cases, e.g.,

$\begin{array}{lll}\text { (2) } & \text { neš.li } & \text { he-w-ax-un } \\ \text { mother(erg) } & \text { neg-m-feed-aor(3) }\end{array}$

c. spatial prefixes: there are two series of spatial prefixes in Dargi containing four prefixes each. The four local prefixes are če- 'on top of', $u$ 'under', $h a$ - 'in front of', $\{e$ - 'behind'; the four directional prefixes are $a$ - 'upwards', $k a$ - 'downwards', sa- 'hither', B-et- 'thither'. The spatial prefixes are the topic of this article. ${ }^{2}$

The order of the three types of prefixes is space-negation-gender, see examples (3)-(5) below.

\subsection{Dargi verb stems}

There are three types of Dargi verb stems ${ }^{3}$ (van den Berg 2001, 33):

a. bare roots, most of which are preceded by a gender prefix. ${ }^{4}$ These roots are free morphemes and occur as independent verbs, e.g.,: $B-a k^{\prime} / B$-a $a$ 'come', B-ax/B-alx 'feed', B-elk'/luk' 'write', B-irz/iz 'milk'.

b. compound stems, which consist of a nominal part (noun, adjective, adverb, sound symbolic element) and a root. The root belong to a limited class of both free morphemes (e.g., $B$-i?/B-ir 'be', $B$-ar/B-ir 'make, do') and bound morphemes (e.g., $B$-uq/B-ulq, B-ik/B-irk). Examples are: tamaša $+B-i ? / B$-ir 'be surprised (surprise+be)', $\hbar \ddot{d} d u r+B-i ? / B$-ir 'be ready (ready+be)', bek' $+B$ -

1 Oblique (i.e., non-absolutive) case endings are added to the absolutive stem plus stem extension, which in most cases is $-l i$.

2 We do not include in this article the petrified prefixes ar- 'away', $l V$ - 'towards' (as in e.g., $a r-B-\ddot{a} q$ ' 'leave', $l \ddot{a}-B-q$ ' 'arrive'). Unlike the spatial prefixes, they combine with a different, very limited, set of verb roots, and their historical origin is unclear.

3 Dargi verbs have a perfective and imperfective stem: the verbal paradigm is partially based on the perfective stem (Aorist, Perfect), partially on the imperfective stem (Future, Imperfect, Present).

${ }^{4}$ Capital $B$ in citation forms stands for the (unspecified) gender prefix, which is realized according to Table 1 . 
$a r / B$-ir 'end (head+do)', $\hbar \ddot{a} d u r+B$-ar $/ B$-ir 'prepare (ready+do)', sugur $+B$ $i ? / B$-ir 'be blind (blind+be)', $q$ 'abul $+B-i k / B$-irk 'agree (agree+aux)', čedi $+B$ $i k / B$-irk 'defeat (above+aux)', $d u r a+B-i k / B$-irk 'appear (outside+aux)', $d u$ $r a+B-u q / B-u l q$ 'leave (outside+aux)', Sela $+B-u q / B-u l q$ 'stay behind (behind+ aux)', hala $+B-u c / B$-urc 'stretch (before+catch)', kus $+B$-ar $/ B$-ir 'set on (onom+do)', q'ic' $+B$-ar $/ B$-ir 'cut with scissors (onom+do)', daldar $+B$-uq/ $B$-ulq 'hang (onom+aux)'.

Beside the gender and the negation affixes, the focus particle - ra 'and, also, even' can also occur between the nominal part and the root of a compound.

c. prefixed stems, which consist of one of the spatial prefixes mentioned in section 1.2 type c. and a root. The root belongs to a limited class of free and bound morphemes. Examples are, e.g., (with the bound morpheme $B$-uq): $a$ $B$-uq 'move impetuously upwards (upwards-aux)', $k a-B-u q$ 'move impetuously downwards (downwards-aux)'; (with the free morpheme $B$-at 'leave, let') $\check{c} e$ $B$-at 'add (on-leave)', $u$-B-at 'plant, bury (under-leave)'. The stems form one phonological unit with word stress on the first syllable, i.e., on the prefix.

The principal difference between compound stems and prefixed stems is, that the nominal part of a compound belongs to an open class, which can be expanded by including borrowed lexemes. In contrast, the prefixes of the stems of type c. are a closed class. The remainder of this paper will deal with the latter type of prefixed verb stems.

\section{Closer look at the spatial prefixes}

\subsection{Form and meaning}

Table 2 gives a schematic overview of the spatial prefixes. The prefixes of the local series can in their turn be followed by a gender affix, thus giving rise to two adjacent gender affixes preceding the root. The prefix followed by the gender affix has an elative meaning, e.g., če- 'on top of', $\check{e} e-B$ - 'from the top'. Examples of a local prefix plus a root are given in (3), of a local prefix with a gender affix plus a root in (4); combinations of a directional prefix plus a root are exemplified in (5). 
Table 2

Spatial prefixes in Akusha Dargi

\begin{tabular}{|l|l|l|l|}
\hline \multicolumn{2}{|c|}{ LOCAL PREFIX } & \multirow{2}{*}{ DIRECTIONAL PREFIX } \\
\hline \multicolumn{2}{|c|}{-gender affix } & \multicolumn{1}{|c|}{+ gender affix } & \\
\hline \hline če- 'on top of' & če-B- 'from the top, off' & ka- 'downwards' \\
\hline u- 'under' & u-B- 'from under' & a- 'upwards' \\
\hline ha- 'in front of' & ha-B- 'from the front' & sa- 'hither' \\
\hline Ye- 'behind' & le-B- 'from behind' & B-et- 'thither' \\
\hline
\end{tabular}

Examples:
(3) (a) če-b-at-ur on-n-leave-aor(3)
(b) če-he-b-at-ur on-neg-n-leave-aor(3)
(c) u-b-at-ur under-n-leave-aor $(3)$
(d) ha-b-at-ur front-n-leave-aor(3)
'(S)he added it.'
'(S)he did not add it.'
'(S)he planted/buried it.'
'(S)he put it in front.'
(4) (a) če-b-b-at-ur on-n-n-leave-aor(3)
(b) če-r-d-at-ur ${ }^{5}$ on-nh-nh-leave-aor(3)
(c) če-b-ћe-b-at-ur on-n-neg-n-leave-aor(3)
'(S)he took it (a piece of clothes) off.'
'(S)he took them (clothes) off.'
'(S)he did not take it off.'
(5) (a) ka-b-at-ur down-n-leave-aor (3)
(b) ka-he-b-at-ur down-neg-n-leave-aor(3)
(c) a-b-at-ur up-n-leave-aor (3)
(d) sa-b-at-ur hither-n-leave-aor(3)
'(S)he put it down.'
'(S)he did not put it down.'
'(S)he put it on a higher place.'
'(The hen) hatched (an egg).'

5 The 3rd person non-human plural gender marker has positionally conditioned allomorphy, with $d$ in morpheme-initial and -medial position, and $r$ in morpheme-final position. The allomorphy of this gender affix serves as the main instrument to distinguish between a gender prefix belonging to a root and a gender suffix belonging to a spatial prefix, as in

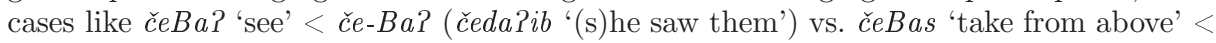
čeB-as (čerasib'(s)he took them'). 


\subsection{Description in the literature}

The literature on Dargi usually does not make a clear distinction between prefixed and compound stems: they are often treated under one heading. The underlined verbs in example (6) are actually compounds with an adverb. Various authors mention the possibility of combining more than one spatial prefix with a root (Abdullaev 1954, 158; Abdullaev 1993, 288-362; Magometov 1963, 175-83; 1983, 196-200), e.g., ${ }^{6}$

" $P a-b$-ik-es 'put upwards, reach, argue', ka-b-ik-es 'fall, happen', b-et-ik-es 'get (thither)', sa-b-ik-es 'get (hither)', b-et-sad-b-ik-es 'get hither-thither, get worried', če-b-ik-es 'tear into', če-?a-b-ik-es 'put on top', če-ka-b-ik-es 'tear into down-

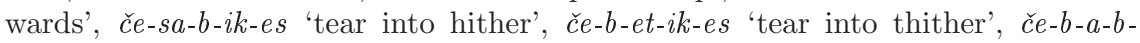

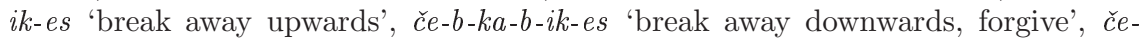
$b$-sa-b-ik-es 'break away hither', če-b-b-et-ik-es 'break away thither', $\check{c} e-b$ - $b$-ik-es

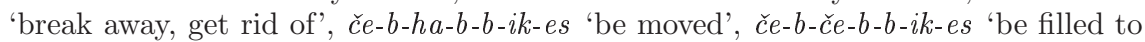

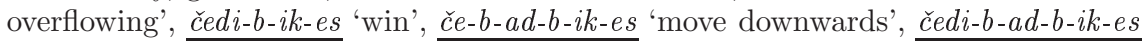

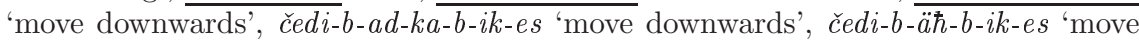

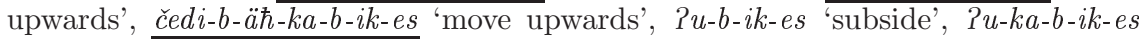

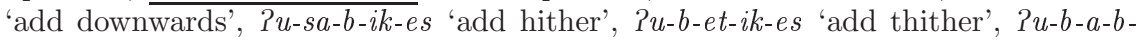
$i k$-es 'break away upwards', $P u-b-k a-b$-ik-es 'break away downwards', $P u-b-s a-b-$ $i k$-es 'break away hither', $? u$-b-b-et-ik-es 'break away thither', $? u$-b-b-ik-es 'step back, confess', $? u-b-\check{c} e-b-b$-ik-es 'cause a scuffle', $? u-b-h a-b-b$-ik-es 'slip out, dodge',

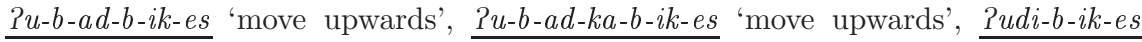

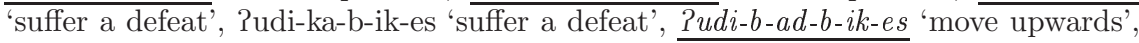

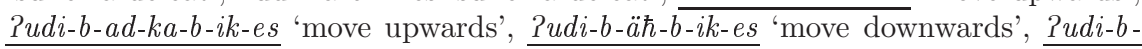
$\overline{a ̈ \hbar-k a-b-i k-e s}$ 'move downwards', ha-b-ik-es 'appear before', ha-ka-b-ik-es 'hinder downwards', $h a-s a-b$-ik-es 'hinder, block hither', ha-b-et-ik-es 'hinder, block thither', $h a-b$-b-ik-es 'tear', $h a-b$ - $k a-b$-ik-es 'tear downwards', $h a-b$-sa-b-ik-es 'tear hither', $h a-b-b$-et-ik-es 'tear thither', hala-b-ik-es 'overtake', hala-b-ad-b-ik-es 'move from

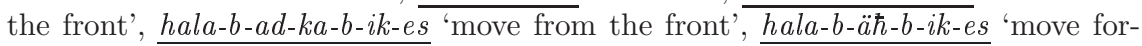

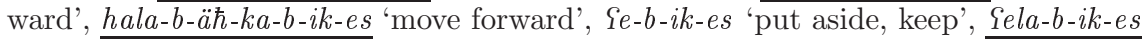
'hide oneself', Yela-ka-b-ik-es 'hide downwards', Sela-sa-b-ik-es 'hide hither', Yela-bet-ik-es 'hide thither', fela-b-ad-b-ik-es 'follow', fela-b-ad-ka-b-ik-es 'follow', Fela-

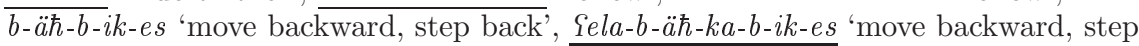
back', $\underline{\text { e-b-ad-b-ik-es }}$ 'get caught upwards'" (Abdullaev 1993, 333-5)

The examples given above suggest that there are virtually no limitations to the combinatory possibilities of local and directional prefixes. This will be tested in section 3 on data from Akusha Dargi.

6 The examples quoted here are combinations with the auxiliary $B-i k / B$-irk. For reasons of space only the perfective stem $B$ - $i k$ is given; morpheme boundaries were inserted for the readers' convenience. Abdullaev indicates glottal stops in initial position before a vowel; as there is no opposition in that position between the absence vs. presence of $/ \mathrm{P} / \mathrm{I}$ do not indicate glottal stops in my own transcription.

Acta Linguistica Hungarica 50, 2003 
As to nexus, Abdullaev $(1954,161 f)$ mentions the possibility of inserting the focus particle -ra 'and, also, even' between the spatial prefix and the root, e.g.:

(6) (a) če-as-ib

on-take-aor(3)

'(S)he took it upon him/herself.'

(b) če-ra as-ib, taman-ra b-ar-ib on-and take-aor(3) end-and n-do-aor(3)

'(S)he took it upon him/herself and finished it.'

In Akusha Dargi, however, the particle - ra cannot be inserted between the spatial prefixes and the verb root: $\check{c} e-r a a s-i b$ from example $(6 \mathrm{~b})$ is regarded as an utterance of a different Dargi dialect. The intersected compound taman$r a b-a r-i b$ is acceptable though (see section 1.3 type b.). The possibility of inserting a focus particle is a second major difference between compound verbs and prefixed verbs, in addition to the distinction between open and closed class membership of the first element, mentioned in section 1.3.

\subsection{Historical development}

Dargi spatial prefixes developed from adverbs. This view is generally accepted, see however Musaev (1983) for a different approach. Given Dargi's basic SOV word order, the adverb was positioned between the object and the verb, and also functioned as an adposition with nouns. In the course of time the adverb/adposition lost its independent status: it turned into a bound morpheme with verbs and grammaticalized as spatial case marking on nouns. ${ }^{7}$

Akusha Dargi has four or five local cases, ${ }^{8}$ which in their bare form indicate 'movement to' (lative). The addition of a gender marker renders 'location' (essive); this marker can be followed by the directional suffix - ad to express 'movement away' (elative), e.g.:

7 The grammaticalization of Dargi adverbs is thus a classic example of this type of historical development as discussed in Hopper-Traugott (1993, 107f).

8 Akusha Dargi has an allative - $\{i$ and an illative for hollow space $-\hbar i$ : both occur with a few nouns only, and some authors consider them variants of (historically) one and the same suffix. More work on Dargi is needed to clarify this matter. 
Table 3

Spatial case-marking in Akusha Dargi

\begin{tabular}{|c|c|c|c|}
\hline & LATIVE & ESSIVE & ELATIVE \\
\hline super & $-\check{c} \mathrm{i}$ & $-\check{c} \mathrm{c}-\mathrm{B}$ & -či-B-ad \\
\hline in (mass) & $-z i$ & $-z i-B$ & -zi-B-ad \\
\hline sub & $-? u$ & $-3 \mathrm{u}-\mathrm{B}$ & -?u-B-ad \\
\hline $\mathrm{ad}$ & $-\mathrm{Ci}$ & $-\Upsilon_{i-B}$ & -Si-B-ad \\
\hline in (hollow) & $-\hbar i$ & $-\hbar i-B$ & $(-\hbar i-B-a d)^{9}$ \\
\hline
\end{tabular}

(7) (a) galga.li-či 'onto the tree' tree-sup

(b) galga.li-či-r 'on (top of) the tree' tree-sup-f

(c) galga.li-či-r-ad 'from the tree' tree-sup-f-ela

(8) (a) GarGa.li-?u 'under the stone' stone-sub

(b) ši.li-zi 'into the village' village-ill

(c) qay- $\mathrm{ii}$ house-ad

'(to) home'

Whereas Akusha Dargi has just one directional suffix - ad, the Urakhi dialect has a set of four elative suffixes, which distinguish directional deixis: - ad 'elative upwards', - $k a d$ 'elative downwards', -sad 'elative towards the speaker, hither', -bit 'elative away from the speaker, thither', e.g., (Uslar 1892, 33):

(9) (a) wac'a.li-zi 'into the forest' forest-ill

(b) wac'a.li-zi-w-ad 'out of the forest upwards' forest-ill-m-ela

(c) wac'a.li-zi-w-kad 'out of the forest downwards' forest-ill-m-ela

(d) wac'a.li-zi-w-sad 'out of the forest towards the speaker' forest-ill-m-ela

9 This form can be obtained in elicitation, but has not occurred so far in Akusha Dargi texts. 
(e) wac'a.li-zi-b-bit 'out of the forest away from the speaker' forest-ill-m-ela ${ }^{10}$

Historically we therefore assume two series of adverbs, the local adverbs (e.g., $\left.{ }^{*} \check{c} V,{ }^{*} ? u,{ }^{*} h a,{ }^{*} \varphi e\right)^{11}$ and the directional ones (e.g., $\left.{ }^{*} a d,{ }^{*} k a d,{ }^{*} s a d\right) .{ }^{12}$ These adverbs grammaticalized, either separately or in combination with each other, as case-endings on nouns and as prefixes on verbs. A schematic representation of these processes is given in Tables $4-5$.

Table 4

Grammaticalization of local adverbs

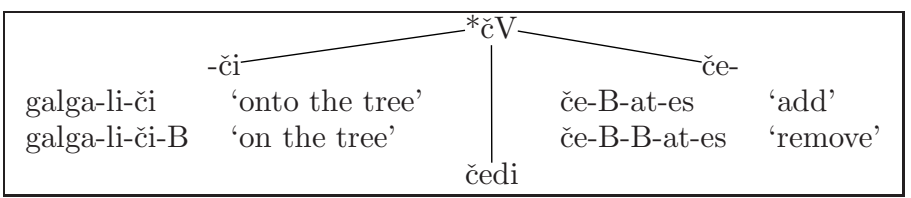

Table 5

Grammaticalization of directional adverbs

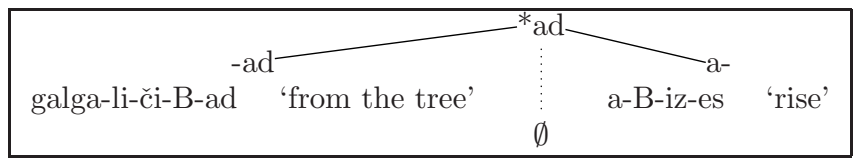

In addition new local adverbs were formed on the basis of the old ones, e.g.: čedi 'on top of, above', udi 'under', hala 'in front of, before', Sela 'behind, after'. ${ }^{13}$ The current adverbs occur independently, e.g.:

10 Apparently with the assimilation of the gender affix: $w-b>b-b$.

11 We can at least reconstruct an adverb ${ }^{*} \check{c} V$, which developed into the case-ending - $\check{c} i$ and prefix $\check{c} e-;$ an adverb $* ? u$, which developed into $-? u$ and $u$-. The adverb ${ }^{*} h a$ developed into a prefix $h a_{-}$, but the location 'in front of' with nouns is expressed in Akusha Dargi by the adposition hala 'in front of', whereas some other dialects have a cognate local suffix. The spatial suffix -zi does not seem to have developed from an adposition. Due to the restricted occurrence of $-\{i$, we cannot be more precise about the relationship between the prefix $\{e$ - and the suffix - $\{i$ at the moment.

12 The directional adverbs $a d, k a d$ and sad lost their final consonant while being attached to verbs: in some dialects the consonant still occurs in negated forms, however, e.g., Urkarakh Dargi $s a-b-a$ - $i b$ (hither-n-come-aor(3)) 'it arrived' vs. sat- $\hbar a-b-a$ - $i b$ (hitherneg-n-come-aor(3)) 'it did not arrive' (Magometov 1963, 232).

13 There is ample evidence that the original adverbs were monosyllabic and that the second

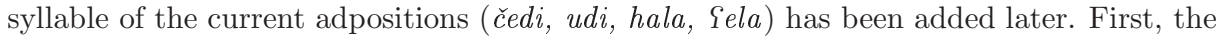




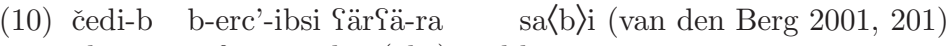
above-n n-fry-part hen(abs)-and be:n

'On top was a fried chicken as well.'

The adverbs are also used in locative constructions, following a noun in the genitive, while taking the same suffixes as the local case-endings, e.g.:

\begin{tabular}{|c|c|c|c|}
\hline 1) (a) & $\begin{array}{l}\text { galga-la } \\
\text { tree-gen }\end{array}$ & $\begin{array}{l}\text { čedi } \\
\text { above }\end{array}$ & '(to) above the tree' \\
\hline (b) & $\begin{array}{l}\text { galga-la } \\
\text { tree-gen }\end{array}$ & $\begin{array}{l}\text { čedi-b } \\
\text { above-n }\end{array}$ & 'above the tree' \\
\hline (c) & $\begin{array}{l}\text { galga-la } \\
\text { tree-gen }\end{array}$ & $\begin{array}{l}\text { čedi-b-ad } \\
\text { above-n-ela }\end{array}$ & 'from above the tree' \\
\hline
\end{tabular}

The adverbs also play a role in verbal compounding, see section 1.3 type b.
(12) urši udzi.li-či-w čedi+ik-ib (van den Berg, fieldnotes)
boy(abs) brother-sup-m above+m:pass-aor(3)
'The boy beat his brother.'

\subsection{Synchronic issues to be explored}

Although it is clear from a diachronic perspective that the prefixes under consideration derive new lexical items, the synchronic description of the prefixed verb stems is still under debate. Some syntagmatic and semantic properties need to be further clarified. Therefore the following questions need to be answered:

a. To what extent do spatial prefixes and verb roots combine freely?

b. To what extent can local and directional prefixes be combined in a verb?

c. Is the meaning of a prefixed verb stem transparent from the combination of meanings of the prefix and the root?

d. Do the spatial prefixes influence valency?

These questions will be discussed in section $\mathbf{3}$ below.

original monosyllabic adverb is still found in some Dargi dialects, e.g., Megeb Dargi $P u$ 'under' vs. Akusha Dargi udi (Magometov 1982, 126). In Akusha Dargi the monosyllabic adverbs are regarded as archaic and are only found in folktales and poetry. An additional argument is the variation of the second syllable across the various dialects, e.g., Akusha čedi, Kubachi čiile 'on'; Akusha udi, Kubachi guule 'under' (Magometov 1963, 244-9). 


\section{Synchronic morphological analysis}

Tables 6-7 give an overview of the combinatory possibilities of nine series of prefixed verb stems. The verbs were taken from the text corpus in van den Berg (2001), which is a sample of Dargi folktales. Additional data were taken from Isaev (1988), and Abdullaev (1993). All prefixed verb stems were checked, whether the root of that verb would also occur with one of the other prefixes. All potential prefix combinations were checked as well. A total number of 21 verb series (i.e., 21 roots with their prefix combinations) was checked. The most elaborate series are given in tables 6-7; the other 12 verb series displayed just a few prefix-root combinations. They were taken into account for the study, but for reasons of space, they will not be fully represented in a table. ${ }^{14}$

14 These 12 verb series are the following: five of them are based on a free morpheme, e.g.,

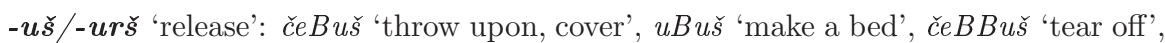
$u B B u \check{s}$ 'give something to someone else to wear out', kaBuš '1. throw, 2. kill', aBuš 'throw into a pan', čekaBuš 'throw upon, cover', ukaBuš 'make a bed';

- erd/-ud 'tear': čeBBerd 'tear off', uBBerd 'tear off', haBBerd 'dig through';

- $\ddot{a} \boldsymbol{q} /-\boldsymbol{i r q}$ 'hit': $\check{c} \boldsymbol{B} \ddot{a} q$ 'put something against something else', $u B \ddot{a} q$ 'put the foundation', haBäq 'throw out with force, chase', čeBBäq 'cut off', $u B B \ddot{a} q$ 'deny';

- erx/-urx 'turn into different form': čeBBerx 'forgive', uBBerx 'leave secretively', $B$-eterx 'realize';

-aq/-iq 'pass': B-etaq 'get lost, disappear', B-etkaq 'get lost, disappear'.

Five other verb series are based on a bound morpheme:

- $\boldsymbol{a c}$ '/-ic': $u B B a c$ ' 'leave from under', $a B a c$ ' 'rise', kaBac' 'leave downwards';

-s/-ys: čes/čeys 'promise', с̌eBas 'take from above', uBas 'take away', haBas 'dig from under, undermine', YeBas 'imitate', as 'buy, take', kas 'take', sas 'take', haBkas 'dig from under, undermine', SeBkas 'imitate';

-rt' (both perfective and imperfective): čert' 'pour on top', čerert'es 'pour out', urert'es 'pour out', ert' '1. cover by glazed frost, 2. add (liquids) into object', kert' 'pour', čekart' 'pour from above';

$-\boldsymbol{q}$ '/-lq ': ‘̌eq' 'strew on top', $u q^{\prime}=a q$ (causative only) 'strew (straw) under (the cattle)', $k a q$ ' 'strew';

-g/-ig: čeg 'hit', ag 'touch', kag 'fall on the floor', čekag 'hit'.

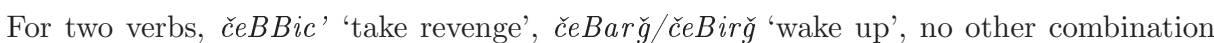
with a prefix was found, nor did the root occur in an other verb. There are two additional verbs that are suspicious with regard to their morphological make-up, but which were not taken into account here, e.g., $\check{c} h / \check{c} e l h$ 'dress' (negative form $\check{c} e-\hbar e-h$ !) and kal/kawl 'stay' (negative form $k a-\hbar e-l !)$. 


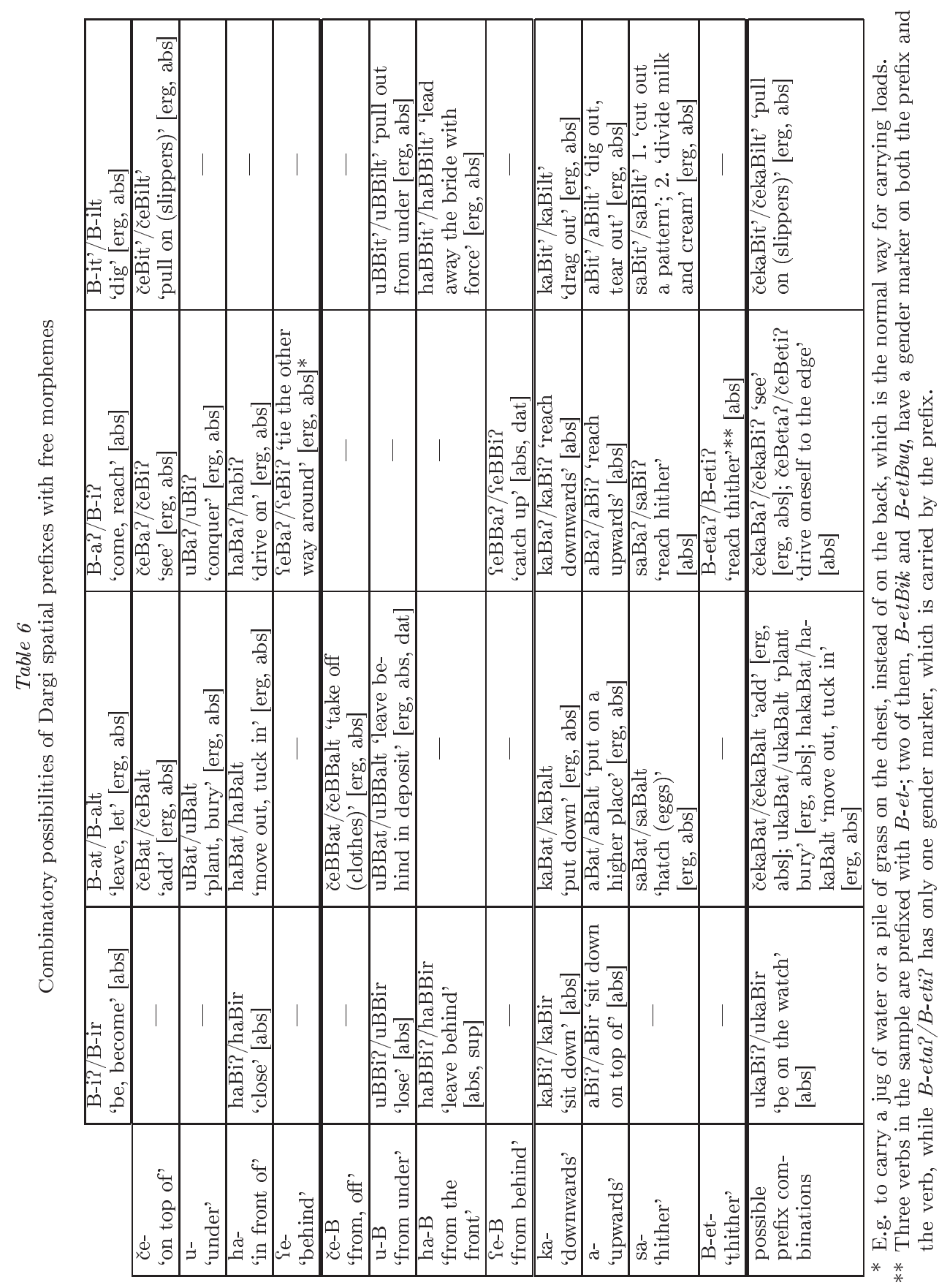

Acta Linguistica Hungarica 50, 2003 


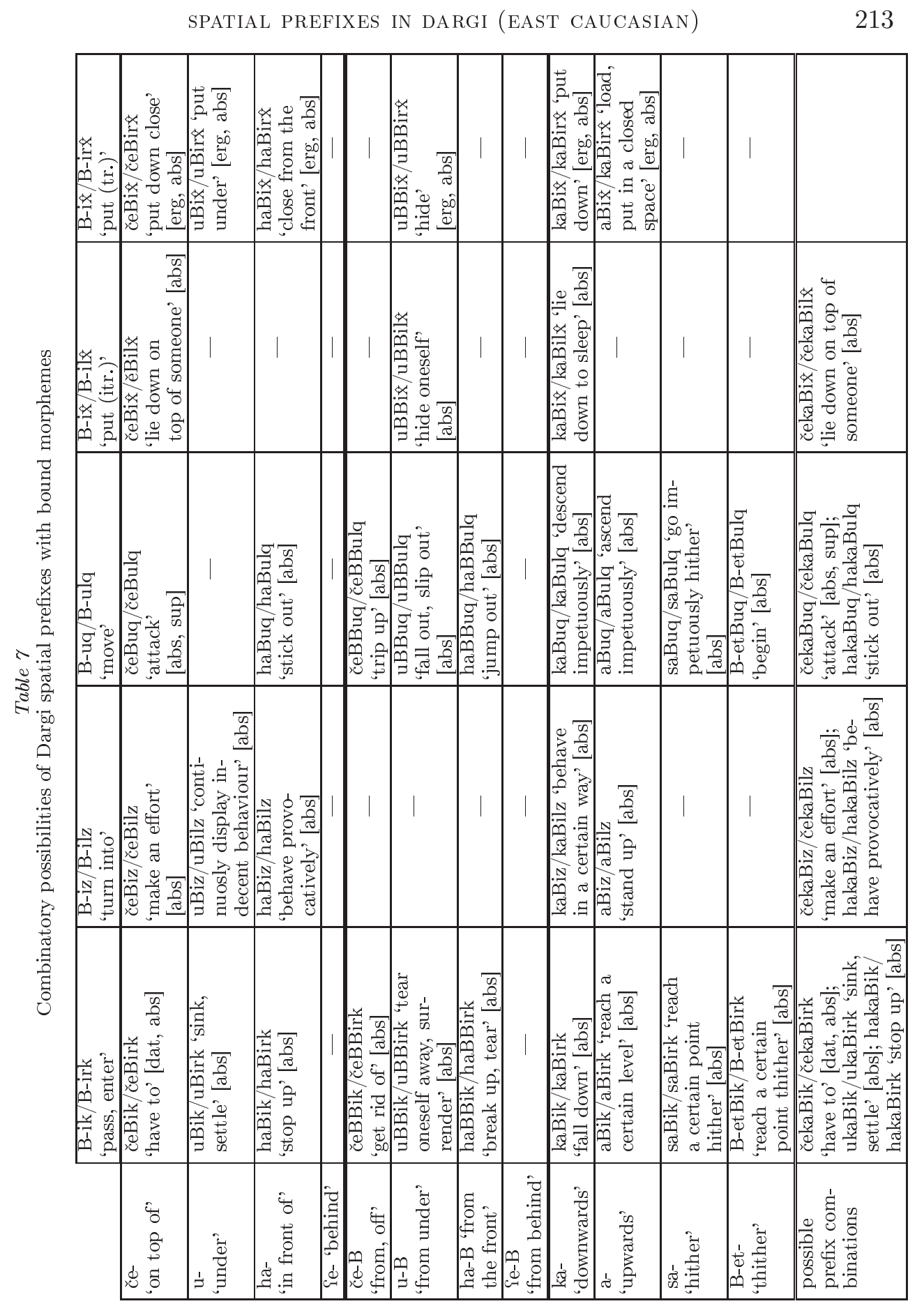

Acta Linguistica Hungarica 50, 2003 


\subsection{Possible morpheme combinations}

Table 6 gives an overview of the combinatory possibilities of the spatial prefixes (in the rows) with verbal roots that are free morphemes (in the columns), viz. $B$-i?/B-ir 'be, become', $B$-at/B-alt 'leave let, $B$-aP/B-i? 'come, reach', and $B$-it' $B$-ilt' 'dig'. Table 7 presents the combinations of the spatial prefixes with verbal roots that are bound morphemes, viz. $B$-ik/B-irk 'pass, enter',

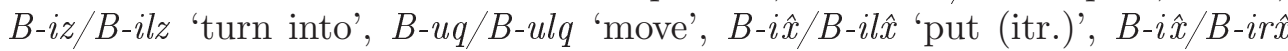
'put (tr.)'. The translation of the bound morphemes only approximates their semantics: the precise meaning of these verbal roots needs further research.

It turns out that no verb series is complete, i.e., there is no verb root that combines with all the spatial prefixes. In general, a local prefix followed by a gender marker only combines with a certain root, if the same prefix also occurs with that root without the gender marker, e.g., čeBBik/čeBBirk 'get rid of' and čeBik/čeBirk 'have to'; haBBuq/haBBulq 'jump out' and haBuq/haBulq 'stick out', etc. There are a few exceptions to this tendency, mainly verbs with the prefix $u$-B-, e.g., $u B B i$ / $u B B i r$ 'lose' (**uBi?/uBir), uBBuq/uBBulq 'slip out' (**uBuq/uBulq); haBBit'/haBBilt' 'lead away the bride with force' (**haBit'/haBilt').

As to the combinatory possibilities of the local and directional prefixes, tables 6-7 show that local prefixes only combine with the directional prefix ka- e.g.,: čeBat/čeBalt 'add' and čekaBat/čekaBalt 'add'; haBuq/haBulq 'stick out' and hakaBuq/hakaBulq 'stick out'; uBik/uBirk 'sink, settle' and $u k a B i k / u k a B i r k$ 'sink, settle'. The presence of $k a$ - does not seem to change the meaning of the verb substantially: probably the semantic difference between verbs with and without $k a$ - is in the process of being lost, or $k a$ - is on its way of becoming a kind of discourse particle, the exact meaning of which is (yet) unknown. The single other combination of prefixes is $\check{c e}$ - and $B$-etin the verb čeBeta?/čeBeti? 'drive oneself to the edge', the meaning of which cannot be related directly to the verbs prefixed with just $\check{c}$ - or $B$-et-, i.e., $\check{c} e B a ? / \check{c} e B i ?$ 'see' and $B$-eta?/B-eti? 'reach thither'.

\subsection{Frequency}

Table 8 gives an overview of the number and percentage of occurrences in the sample of 21 verb series tested here and in the corpus. Combinations with $k a-$, $\check{c} e$ - and to a lesser extent $a$ - are the most frequent, both for token and type frequency. An interesting discrepancy is observed between the large number 
of theoretically possible combinations with $u$ - and $u$-B- and their much lower frequency in the corpus. This holds to a lesser extent also for $h a-$ and $h a-B$-.

Table 8

Number of occurrences of spatial prefixes

\begin{tabular}{|l|c|c|c|c|c|c|}
\cline { 2 - 7 } \multicolumn{1}{c|}{} & \multicolumn{2}{c|}{$\begin{array}{c}\text { OCCURRENCES IN } \\
\text { SAMPLE }\end{array}$} & \multicolumn{2}{c|}{$\begin{array}{c}\text { OCCURRENCES IN } \\
\text { CORPUS (TOKENS) }\end{array}$} & \multicolumn{2}{c|}{$\begin{array}{c}\text { OCCURRENCES IN } \\
\text { CORPUS (TYPES) }\end{array}$} \\
\cline { 2 - 7 } \multicolumn{1}{c|}{} & number & percentage & number & percentage & number & percentage \\
\hline če- + če-B- & $15+9$ & 23.3 & $57+10$ & 26.2 & $7+6$ & 27.7 \\
\hline $\mathrm{u}-+$ u-B- & $8+14$ & 21.4 & $1+3$ & 1.6 & $1+3$ & 8.5 \\
\hline ha- + ha-B- & $8+6$ & 13.6 & $2+3$ & 1.9 & $1+2$ & 6.4 \\
\hline Ie- + fe-B- & $1+3$ & 3.9 & $0+1$ & 0.4 & $0+1$ & 2.1 \\
\hline a- & 15 & 14.5 & 35 & 13.7 & 8 & 17.0 \\
\hline ka- & 15 & 14.5 & 119 & 46.5 & 13 & 27.7 \\
\hline sa- & 6 & 5.8 & 5 & 1.9 & 2 & 4.2 \\
\hline B-et- & 3 & 2.9 & 20 & 7.8 & 3 & 6.4 \\
\hline TOTAL & 103 & 100 & 256 & 100 & 47 & 100 \\
\hline
\end{tabular}

\subsection{Semantic properties}

The meaning of a prefixed verb is transparent in some cases, in particular when the directional prefixes are contrasted with each other, e.g., kaBik/ kaBirk 'fall down', aBik/aBirk 'reach a certain level', saBik/saBirk 'reach a certain point hither', B-etBik/B-etBirk 'reach a certain point thither' or $k a B u q / k a B u l q$ 'descend impetuously', aBuq/aBulq 'ascend impetuously', saBuq/saBulq 'go impetuously hither' (but not B-etBuq/B-etBulq 'begin'). Some verb stems that contain a prefix plus gender marker, indicate a movement opposite to the movement encoded in the corresponding stems with the bare prefix, e.g., čeBat/čeBalt 'add' vs. čeBBat/čeBBalt 'take off'; haBik/ haBirk 'stop up' vs. haBBik/haBBirk 'tear'. Other verb pairs of this type do not show a direct semantic corrrespondence (anymore), e.g., uBat/uBalt 'plant, bury' and uBBat/uBBalt 'leave behind in deposit'; $9 e B a$ / $/ e B i$ ? 'tie the other way around' and $\mathcal{I} e B B a$ P $/ \mathrm{Y} e B B i$ ? 'catch up'.

In most cases, however, the meaning of a verb can be remotely reconstructed from the components. This is only possible 'in hindsight', i.e., af-

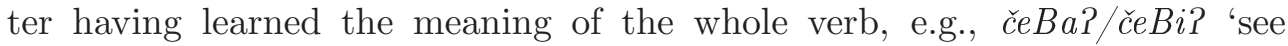
(< on+reach?)', saBat/saBalt 'hatch eggs (< hither+leave)', haBiz/haBilz 'behave provocatively (< in front+turn into?)', haBBit'/haBBilt' 'lead away the bride with force ( $<$ from the front+dig?)', etc.

In general, intransitive prefixed verbs are derived from an intransitive root and transitives from transitive roots. A few valency changes can be 
observed however, e.g., čeBa?/čeBi? 'see', uBa?/uBi? 'conquer', haBa?/haBi? 'drive on', $\{e B a$ ? $/ \mathcal{S} B i$ ? 'tie the other way around' are transitive, although the simplex verb $B$ - $a$ P $B$ - $i$ ? 'come, reach' is intransitive. One could of course decide that these verbs are derived from a different, homophonous, root, also in the light of the semantic differences between the root and the derived stems. Alternatively, one would have to allow for the possibility of valency changes in the derivation by spatial prefixes.

\subsection{Conclusion for the Dargi data}

Given the morphological and semantic peculiarities of the Dargi prefixed verb stems described above, we conclude that these stems must be regarded as one whole. Therefore we propose to analyze these Dargi verbs as bipartite stems ${ }^{15}$ consisting of two morphemes, the spatial prefix and the root. The concept of bipartite stems was first introduced for East Caucasian languages by Johanna Nichols (see also section 4.1 below), who defined it as follows:

\footnotetext{
"A bipartite verb stem consists of two morphemes, which make up a single, and often discontinuous, stem. One of the morpheme slots usually has to do with motion, direction, the other on with means, shape classification. The morphemes of at least one, but sometimes both, slots are likely to be a closed class or otherwise limited." (Nichols 2000, based on DeLancey 1996)
}

The arguments for treating the Dargi verb stems under consideration as bipartite are the following:

a. Syntagmatic arguments: the prefixed verb stems are one phonological word. The nexus between the two parts is fairly tight: only the gender and negation affixes may interrupt the stem, but not the focus particle (section 1.3). The data presented in section $\mathbf{3 . 1}$ have shown that there is a limited amount of possible combinations of roots and prefixes: roots do not combine freely with just any prefix. Combinations with the prefixes $\check{c} e^{-}, k a-$ and $a$ - are significantly more frequent than with other prefixes (section 3.2). There is a constraint on the occurrence of the local prefix with a gender marker when the prefix does not also occur without a gender marker with the same verb root. Finally, there are fewer possibilities for combining local and directional prefixes in one stem than the literature suggested.

15 According to DeLancey $(1996,37)$ the term 'bipartite stem' comes from Jacobsen (1980), which I was unable to consult.

Acta Linguistica Hungarica 50, 2003 
b. Paradigmatic arguments: the prefixes come from a closed class, the roots from a limited class of bound and free morphemes. Half of the roots are bound morphemes and do not occur as independent verbs, i.e., the paradigmatic absence of a prefix does not render a semantically and syntactically meaningful verb stem.

c. Semantic arguments: the data discussed in section $\mathbf{3 . 3}$ have shown that most verbs display considerable semantic differences between the root and prefixed stems derived from that root. Valency changes have to be accounted for in addition.

These arguments lead us to conclude that the Dargi prefixed stems must be regarded as lexicalized, inseparable combinations of a prefix and a root, i.e., as bipartite stems. As some roots occur as free stems and others do not, it seems that some stems are more lexicalized than others.

Taking up the issue of nexus once more, Dargi bipartite stems can be interrupted by two types of elements, i.e. the gender and negation affixes, as in example $(3 \mathrm{~b})$, repeated here for convenience.
(13) če-he-b-at-ur
'(S)he did not add it.'
Dargi
on-neg-n-leave-aor(3)

The insertion of inflectional affixes between two parts of a single prosodic and grammatical word is in no way unique for Dargi, e.g., the Dutch past gerund marker ge- (14); the negation marker in Hungarian (example (15), Perrot 1995, 110); endoclitic person markers in Udi (example (16), Harris 2002, 123):
(14) op-ge-sloten
on-partic-lock:partic
'locked up'
Dutch
(15) e prev neg go-pst(3)
'did not leave'
Hungarian
(16) mzia-n arux-ne-be
'Mzia built a fire.'
Udi
Mzia-erg fire-3sg-do-aor

In the process of lexicalization of the spatial prefix and the root, the Dargi gender and negation affixes got entrapped between the two morphemes of the stem. As a result they have become infixes with bipartite stems. Of course, the base that is split is not a single morpheme - as in the strict definition of infixation. The two morphemes that make up the bipartite stem, however, bear a closer semantic and phonological relation to each other than they do 
to the infixed markers (see for a discussion of this type of infixes, Moravcsik 2000, 546).

Example (13) will therefore be reanalyzed as:

$\left(13^{\prime}\right)$ če $\langle$ he $\rangle\langle b\rangle$ at-ur add:neg:n-aor(3)

$$
\text { '(S)he did not add it.' Dargi }
$$

\section{Bipartite stems in other languages}

The analysis of the Dargi verbs under consideration as bipartite stems fits in with a pattern more widely found in verb stems in East Caucasian languages and other language families.

\subsection{East Caucasian context}

The East Caucasian language family is divided in 6 branches: Nakh, AvarAndic, Tsezic, Lak, Dargi, Lezgic. Topuria (1983) and Sulejmanov (1992), among others, noted the presence of spatial elements in the initial part of verb stems, while working from a historical-comparative point of view.

In Ingush, a language of the Nakh branch, verbs have discrepant initials and vocalism, but clearly related meanings. The spatial elements are found in stem-final position, whereas the initial elements do not have a discernible meaning, see Table 9 (Nichols 2000). ${ }^{16}$

Table 9

Spatial elements in Ingush verb stems

\begin{tabular}{|c|c|c|}
\hline -tt 'vertical/standing' & $\begin{array}{l}\text {-ss 'throw, cause to } \\
\text { move through air' }\end{array}$ & $\begin{array}{l}\text {-ll 'lying/spreading } \\
\text { over surface' }\end{array}$ \\
\hline $\begin{array}{l}\text { ott 'stand up' } \\
\text { Dott 'pour, lay foundation' } \\
\text { laatt 'stand' (progressive) } \\
\text { ghott 'fly away, take off' }\end{array}$ & $\begin{array}{l}\text { Doss 'descend'? } \\
\text { toss 'sprinkle, strew' } \\
\text { qoss 'throw, cast' } \\
\text { moss 'splash, pour water' }\end{array}$ & $\begin{array}{l}\text { oll 'hang up' } \\
\text { Dull 'put, cover' } \\
\text { toll 'put on top' } \\
\text { qoll 'throw, cast' } \\
\text { ull 'lie' }\end{array}$ \\
\hline
\end{tabular}

Nichols proposes the concept of bipartite stems in the first place to be able to account for this synchronic state of affairs in the modern Nakh languages. In

${ }^{16}$ Capital $D$ denotes the (unspecified) gender marker.

Acta Linguistica Hungarica 50, 2003 
addition, the bipartite concept would also explain some historical-comparative facts of East Caucasian, ${ }^{17}$ like, e.g., the presence of discrepant initials in otherwise cognate verb sets, or the different position of gender markers in the various branches of the language family (prefixal in Nakh, Avar-Andic, both prefixal and infixal in Lak, Dargi, Lezgic). More details and arguments are given in Nichols (2000).

Hunzib, which belongs to the Tsezic branch, has a few verbs with remnants of spatial prefixes. All verbs are given in Table 10 (van den Berg $1995,353)$.

\section{Table 10}

Spatial elements in Hunzib verb stems

\begin{tabular}{|c|c|c|}
\hline *g- 'downwards' & *n-/r- 'upwards' & $*_{\text {t- }}$ 'horizontal' \\
\hline $\begin{array}{l}\text { gu 'come down (precipitation)' } \\
\text { guc'u 'show up' } \\
\text { guuc'u 'look' (Nakhada dial.) } \\
\text { gušu 'touch downwards' } \\
\text { guk' 'put on (a hat, scarf)' } \\
\text { gul 'put down' }\end{array}$ & $\begin{array}{l}\text { nu 'come hither' } \\
\text { ruc'u 'show up' } \\
\text { nuuc'u 'look' (Hunzib dial.) } \\
\text { ruk' 'belch' }\end{array}$ & $\begin{array}{l}\text { tu 'come thither' } \\
\text { tuc'u 'show up' } \\
\text { tuuc'u 'look' } \\
\text { tušu 'touch' }\end{array}$ \\
\hline
\end{tabular}

Except for the verb series $g u / n u / t u$ 'come', the spatial dimension of the verbs is currently only known by the elder generation. Younger people use the verbs at random or have generalized one of them. These verbs indicate gender agreement by apophony, e.g., (van den Berg 1995, 80):
(17)
(a) ože boy $(\mathrm{abs})$
nə-r
come:I-pst
'The boy came.'
(b) kid
ni-r $\operatorname{girl}(\mathrm{abs}) \quad$ come:II-pst

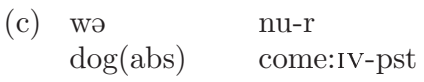
'The girl came.'
'The dog came.'

Rutul, a language of the Lezgic branch, has 7 spatial prefixes: $s$ - 'down, beneath', $l$ - 'on, above', $k$ - 'in solid mass, in contact', $g$ - 'under', 2 - 'inside', $q$ 'behind, back', '̆g- 'outside', $x$ - 'by, around, in the hands of'. Some verb series are given in Table 11 (Alekseev 1994, 227).

17 Nichols (2000) uses the term Nakh-Daghestanian language family, where I use East Caucasian language family. My use of the term East Caucasian does not necessarily imply a further connection of these languages to a larger North Caucasian stock and equals the term Nakh-Daghestanian. 
Table 11

Spatial elements in Rutul verb stems

\begin{tabular}{|c|c|c|c|c|c|}
\hline & -äčw & -eyg & -ağw & $-i \hat{x}$ & -ayč \\
\hline $\begin{array}{l}\text { s- } \\
\text { 'down, beneath' }\end{array}$ & $\begin{array}{l}\text { säč'was } \\
\text { 'dismount' }\end{array}$ & $\begin{array}{l}\text { seygas } \\
\text { 'pour down (rain)' }\end{array}$ & $\begin{array}{l}\text { sağwas } \\
\text { 'set down' }\end{array}$ & & $\begin{array}{l}\text { sayčes } \\
\text { 'scatter' }\end{array}$ \\
\hline 'on, above' & $\begin{array}{l}\text { läč'was } \\
\text { 'climb up' }\end{array}$ & $\begin{array}{l}\text { leyges } \\
\text { 'grow' }\end{array}$ & \begin{tabular}{|l} 
lağwas \\
'set up'
\end{tabular} & \begin{tabular}{|l} 
lix̂es \\
'put on'
\end{tabular} & $\begin{array}{l}\text { layčes } \\
\text { 'jump, fly' }\end{array}$ \\
\hline $\begin{array}{l}\mathrm{k}- \\
\text { 'in a solid mass' }\end{array}$ & $\begin{array}{l}\text { käč'was } \\
\text { 'enter (water)' }\end{array}$ & & \begin{tabular}{|l} 
kağwas \\
'lose'
\end{tabular} & \begin{tabular}{|l} 
kix̂es \\
'bury'
\end{tabular} & \\
\hline 'under' & $\begin{array}{l}\text { gäč'was } \\
\text { 'crawl under' }\end{array}$ & & & \begin{tabular}{|l|} 
gix̂es \\
'put under'
\end{tabular} & $\begin{array}{l}\text { gayčes } \\
\text { 'crawl under' }\end{array}$ \\
\hline $\begin{array}{l}- \\
\text { 'inside' }\end{array}$ & $\begin{array}{l}\text { äč'was } \\
\text { 'enter' }\end{array}$ & $\begin{array}{l}\text { eygas } \\
\text { 'round up cattle' }\end{array}$ & \begin{tabular}{|l} 
ağwas \\
'let in'
\end{tabular} & \begin{tabular}{|l} 
ix̂es \\
'place in' \\
\end{tabular} & \\
\hline $\begin{array}{l}\text { '- } \\
\text { 'behind, back' }\end{array}$ & & $\begin{array}{l}\text { qeygas } \\
\text { 'catch up' }\end{array}$ & & & \\
\hline $\begin{array}{l}\check{g}_{-} \\
\text {'outside' }\end{array}$ & & $\begin{array}{l}\text { ğeygas } \\
\text { 'drive out (cattle)' }\end{array}$ & \begin{tabular}{|l|} 
ğağwas \\
'hatch out'
\end{tabular} & $\begin{array}{l}\text { ğî̂ंes } \\
\text { 'beat' }\end{array}$ & \\
\hline $\begin{array}{l}\mathrm{x}- \\
\text { 'by, around' }\end{array}$ & & & & $\begin{array}{l}\text { xix̂es } \\
\text { 'apply, put } \\
\text { next to' }\end{array}$ & \\
\hline
\end{tabular}

Rutul prefixed verbs indicate gender agreement by infixes which entail some morphonological changes, e.g., (Maxmudova 2001, 14):

\begin{tabular}{|c|c|c|c|}
\hline (a) & $\begin{array}{l}\text { dux } \\
\text { boy(abs) }\end{array}$ & $\begin{array}{l}\text { li〈y〉či-ri } \\
\text { jump:I-pst }\end{array}$ & 'The boy jumped.' \\
\hline (b) & $\begin{array}{l}\text { rì̌s } \\
\text { girl (abs) }\end{array}$ & $\begin{array}{l}\text { le }\langle r\rangle c ̌ i-r i \\
\text { jump:II-pst }\end{array}$ & 'The girl jumped.' \\
\hline (c) & $\begin{array}{l}\text { c'ii } \\
\text { goat(abs) }\end{array}$ & $\begin{array}{l}\text { li〈w }\rangle c ̌ i-r i \\
\text { jump:III-pst }\end{array}$ & 'The goat jumped.' \\
\hline (d) & $\begin{array}{l}\text { yiz } \\
\text { snow(abs) }\end{array}$ & $\begin{array}{l}\text { li〈y〉či-ri } \\
\text { jump:IV-pst }\end{array}$ & 'The snow flew.' \\
\hline
\end{tabular}

In some other Lezgic languages, viz. Tsakhur and Kryz, the gender infixes cause more morphonological changes in the stem, which boils down to apophony. There seems to be a sliding scale with regard to the level of morphonological changes instigated by gender infixes: one minor morphonological change in Dargi, ${ }^{18}$ some, or even considerable, morphonological changes in

18 Verb forms with masculine gender agreement undergo two morphonological changes, /awi/ > /ay/ and /ewa/ > /e/, e.g., ka.yk-ib (fall:m-aor(3)) 'he fell' $(<k a\langle w\rangle i k$-ib), če?-ib (see:m-aor(3)) '(s)he saw him' (< če $\langle w\rangle a$ ?-ib).

Acta Linguistica Hungarica 50, 2003 
Lezgic, apophony in Hunzib. The level of morphonological changes caused by the gender infixes in its turn reflects the different levels of lexicalization (univerbation) of the verb stems in these languages.

\subsection{Other languages with bipartite stems}

Bipartite stems have long been noted for a number of languages of western North America, in particular for Washo, Klamath, Sahaptin, Yana, and Atsugewi, and, to a lesser extent for some surrounding languages. They were initially described in terms of instrumental prefixes and locative suffixes. According to DeLancey $(1996,38)$, however, these terms do not cover the whole semantic range of the initial part, and underspecify the meaning of the final part of the stem. They also seem to imply a grammatical phenomenon, instead of a lexical one. DeLancey therefore proposes the terms 'lexical prefixes' and 'locative-directive stems'.

The lexical prefixes in Klamath are bound morphemes; most of them occur with locative-directional stems only, some also with free stems. They can be roughly divided into three groups (DeLancey 1999, 64-7):

a. classifying lexical prefixes, e.g., c'a 'handful of granular objects', c'i 'liquid in container', c'in 'act with the back', l'oc 'act with the knee', ksV 'living object', ne 'flat object' sci 'bunch of objects', $P i$ 'plural objects'. Examples of bipartite stems are, e.g., lewa 'round object in(to) water', neq'ya 'flat object in(to) the road'.

b. instrumental lexical prefixes, e.g., c'le 'act with finger(nail)s', $d V$ 'act with hands, fingers: rub, knead', $k V$ 'act with a pointed instrument', $k t$ 'hit with fist, kick', $n$ 'act with a round instrument, act upon a round object', $s$ 'act with a sharp instrument, stab', $y V$ 'act with the foot, feet, act violently'. Examples of bipartite stems are, e.g., qew'a 'break in two (itr.)', tqew'a 'break with a blow, kick', nqew'a 'break with a round instrument'.

c. motion and miscellaneous lexical prefixes, e.g., $c V$ 'sg. sit, slide', $l w$ ' $V l w$ 'pl. stand', $t g V$ 'sg. stand', $g V$ 'go, move of one's own volition', $c V$ 'go (group of animals)', hod 'sg. run, jump'. Examples of bipartite stems are, e.g., gewa 'go into water', howwa 'run, jump into water', tgewa 'stand in water'.

The locative-directive stems cover the semantic fields of direction, path and location. They are bound morphemes, always occur as the final element 
of a compound stem, and combine freely with both motional and shapeclassifying initials. The Klamath bipartite stem can be interrupted by a small number of affixes marking reflexive and causative categories (DeLancey 1996, 42; 1999, 59).

The languages of the area display various degrees of grammaticalization (DeLancey's terminology), i.e., they vary considerably in the number of lexical prefixes and locative-directive stems and also differ to whether these are bound or free morphemes. For instance, the locative-directive stems in $\mathrm{Nez}$ Perce are a small closed class of bound morphemes; in Chinookan, it is a small closed class of stems, half of which is bound, half of which occurs independently as well; Klamath has a large closed class of bound morphemes (DeLancey 1996, 42).

The overall correspondences between the languages discussed by DeLancey and the East Caucasian languages are rather striking. In both areas the prefixes and the roots to which they are attached are usually bound morphemes that form a closed class. The languages in DeLancey's sample display different stages of univerbation, as do the various East Caucasian languages: whereas the Dargi bipartite stems are still rather transparent, other East Caucasian languages, like Rutul, Tsakhur, Kryz, and Hunzib, seem to have lexicalized their bipartite stems to a larger extent.

There are differences between the two areas as well: first, the western North American languages seem to have large groups of lexical prefixes and, sometimes, as in Klamath, locative-directive stems. As a result, bipartite stems form a considerable part, -for Klamath even the majority- of verb stems in these languages. The role of bipartite verb stems in East Caucasian seems to be much more modest, e.g., eight prefixes and some 20 odd roots making up a hundred of bipartite verb stems in Dargi. Furthermore, the Dargi and other East Caucasian prefixes are very different semantically: they have a local or directional meaning, which does not seem to be part of the semantics of the lexical prefixes treated by DeLancey.

If we regard bipartite stems as a particular kind of complex verbs, we might be able to come across bipartite stems in those languages, for which complex verbs have been described, e.g., the languages of Northern Australia. The overview of complex verbs given by Schultze-Berndt (forthc.) provides at least two languages, in which possible candidates for a bipartite stem analysis can be found, i.e., Mangarrayi and Nunggubuyu, both belonging to the NonPama-Nyungan stock of languages.

One type of complex verbs in Mangarrayi is described as a compound construction: it has a large set of initial elements, the majority of which is 
bound, and a closed class of auxiliaries which also occur as free morphemes. The compound is a single phonological and morphological word and cannot be interrupted by other elements (Merlan 1982, 123-31), e.g., (example from Merlan 1982, 68, transcription from Schultze-Berndt forthc.):

(19) ngiyan-galij-ma-ny 'He reported to us.'

3sg:1pl-report-aux-pst

A subset of the complex verbs in Nunggubuyu, called auxiliary compounds, consists of a large set of bound initial elements connect to one verb root -bu/-wu, which also occurs as the independent verb 'hit, kill' (Heath 1984, 470). A problematic point in the analysis of these stems in Mangarrayi and Nunggubuyu is that the initial parts seem to lack the spatial, instrumental or classifying semantics typical for bipartite stems of western North America and the East Caucasus. This may however be a matter of analysis.

On the basis of language-internal and comparative evidence, SchultzeBerndt (forthc.) argues that Northern Australian languages have gone through several cycles of complex verb formation. Different stages in this cycle are reflected by the synchronically observable types: the type of stems exemplified above, which can probably be analyzed as bipartite stems, is then one stage of that development. This might be an assumption worth exploring for East Caucasian languages as well.

\section{Conclusion and outlook}

Although the Dargi prefixes have a clear diachronic background of deriving prefixed stems, this approach is not suitable for synchronic description as well. Prefixation is not a free derivational process in Dargi anymore: the prefixes and the majority of roots, to which they are attached, are closed classes of bound morphemes. The concept of bipartite stems proposed here for Dargi provides a more coherent morphological analysis of the data. In addition, it has the advantage of having a broader application to the whole East Caucasian language family. A further area of research could be the semantics of the bound roots, which might be found in the 'path of an event', e.g., $r t$ ' 'pour fluids', $l q$ ' 'strew granular material', - $i k$ 'gradual/involuntary movement', - $u q$ 'voluntary/telic movement', - $i t$ ' 'pull', - $i \hat{x}$ 'put' etc. The bipartite approach presents a stimulating point of view for the synchronic analysis of the verbal morphology of East Caucasian languages, with repercussions for the historical-comparative analysis of these languages as well. 


\begin{abstract}
Abbreviations
I, II, III, IV = gender markers for systems with more than 3 genders; $1,2,3=1$ st, 2nd, 3rd person; abs = absolutive; ad $=$ adlative $;$ aor $=$ aorist; aux $=$ auxiliary, dat $=$ dative; ela = elative; erg = ergative; $\mathrm{f}=$ feminine; gen = genitive; ill = illative; $\mathrm{m}=$ masculine; $\mathrm{n}$ $=$ neuter; neg = negation; $\mathrm{nh}=$ non-human plural; onom (onomatopeia) $=$ sound symbolic element; part $=$ past participle; partic $=$ particle $; \mathrm{pl}=$ plural; prev $=$ preverb $;$ pst $=$ past $; \mathrm{sg}$ $=$ singular; sub $=$ sublative; $\sup =$ superlative.
\end{abstract}

\title{
References
}

Abdullaev, Said N. 1954. Grammatika darginskogo jazyka (fonetika i morfologija) [A grammar of Dargi: phonetics and morphology]. Dagestanskij filial AN SSSR, Maxačkala.

Abdullaev, Zapir G. 1993. Darginskij jazyk. Tom II Morfologija [The Dargi language. Vol. II Morphology]. Nauka, Moskva.

Alekseev, Mikhail E. 1994. Rutul. In: Rieks Smeets (ed.) The indigenous languages of the Caucasus, vol. 4, part 2, 213-58. Caravan, Delmar.

Berg, Helma E. van den 1995. A grammar of Hunzib (with texts and lexicon). Lincom, Munich.

Berg, Helma E. van den 2001. Dargi folktales. Oral stories from the Caucasus with an introduction to Dargi grammar. Research School of Asian, African and Amerindian Studies, Leiden.

DeLancey, Scott 1996. The bipartite stem belt: disentangling areal and genetic correspondences. In: D. Librik - R. Beeler (eds) BLS 22: Special session on Historical Issues in Native American Languages, 37-54. Berkeley Linguistic Society, Berkeley.

DeLancey, Scott 1999. Lexical prefixes and the bipartite stem construction in Klamath. In: International Journal of American Linguistics 65 : 56-83.

Harris, Alice C. 2002. Endoclitics and the origins of Udi morphosyntax. Oxford University Press, Oxford.

Heath, Jeffrey 1984. Functional grammar of Nunggubuyu. Australian Institute of Aboriginal Studies, Canberra.

Hopper, Paul-Elizabeth Traugott 1993. Grammaticalization. Cambridge University Press, Cambridge.

Isaev, Magomedshapi A. 1988. Russko-darginskij slovar'. Dagučpedgiz, Maxačkala.

Jacobsen, William 1980. Washo bipartite verb stems. In: K. Klar et al. (eds) American Indian and Indoeuropean Studies. Papers in honor of Madison S. Beeler, 85-99. The Hague, Mouton.

Magometov, Alexandr A. 1963. Kubačinskij jazyk. Issledovanie i teksty [The Kubachi language: investigation and texts]. Mecniereba, Tbilisi.

Magometov, Alexandr A. 1982. Megebskij dialekt darginskogo jazyka [The Megeb dialect of Dargi]. Mecniereba, Tbilisi.

Magometov, Alexandr A. 1983. Sistema posleložnyx padežej i preverbov v darginskom jazyke [The system of postpositional cases and preverbs in Dargi]. In: Sistema preverbov i poslelogov v iberijsko-kavkazskix jazykax, 191-202. Institut Istorii, filologii i èkonomiki, Čerkessk.

Acta Linguistica Hungarica 50, 2003 
Maxmudova, Sveta M. 2001. Morfologija rutul'skogo jazyka [A morphology of Rutul]. RAN, Moskva.

Merlan, Francesca C. 1982. Mangarayi. North Holland, Amsterdam.

Moravcsik, Edith A. 2000. Infixation. In: Geert Booij-Christian Lehmann-Joachim Mugdan (eds) Morphologie: ein internationales Handbuch zur Flexion und Wordbildung, vol. I, 545-52. Walter de Gruyter, Berlin \& New York.

Musaev, Magomedsaid M. 1983. Padežnye okončanija i ix genetičeskie paralleli v sisteme preverbov i poslelogov darginskogo jazyka [Case-endings and their genetic parallels in the system of preverbs and postpositions in Dargi]. In: Sistema preverbov i poslelogov v iberijsko-kavkazskix jazykax, 255-62. Institut Istorii, filologii i èkonomiki, Čerkessk.

Nichols, Johanna 2000. Bipartite verb stems in Proto-Nakh-Daghestanian. Invitated paper at the 10th Caucasian Colloquium of the Societas Caucasologica Europæa. Munich.

Nikolayev, Sergey L.--Sergey A. Starostin 1994. A North Caucasian Etymological Dictionary. Asterisk, Moscow.

Perrot, Jean 1995. Préverbes et suffixes casuels en hongrois. In: A. Rousseau (ed.) Les préverbes dans les langues d'Europe. Introduction à l'étude de la préverbation, 107-26. Presses Universitaires du Septentrion, Lille.

Schultze-Berndt, Eva forthc. Preverbs as an open word class in Northern Australian languages: synchronic and diachronic correlates. In: Geert Booij-Ans van Kemenade (eds) Yearbook of Morphology 2002. Kluwer, Dordrecht.

Sulejmanov, Nadir D. 1992. K istorii formirovanija napravitel'nyx morfem s vertikal'noj orientaciej v dagestanskix jazykax [Towards the diachronic developments of directional morphemes with a vertical orientation in Daghestanian languages]. In: Problemy sravnitel'noistoričeskogo issledovanija morfologii jazykov Dagestana, 108-30. DNC RAN, Maxačkala.

Topuria, Guram V. 1983. K istorii vzaimootnošenija predlogov i posleložnyx padežej v lezginskom jazyke [Towards the diachronic relationship of preverbs and postpositional cases in Lezgian]. In: Sistema preverbov i poslelogov v iberijsko-kavkazskix jazykax, 203-6. Institut Istorii, filologii i èkonomiki, Čerkessk.

Uslar, Petr K. 1892. Ètnografija Kavkaza. Jazykoznanie V. Xjurkilinkskij jazyk [Ethnography of the Caucasus. Linguistics V. The Hurkili language]. Upravlenie Kavkazskago Učebnago Okruga, Tiflis.

Address of the author: Helma van den Berg

Max Planck Institute for Evolutionary Anthropology

Inselstrasse 22

04103 Leipzig

vandenberg@eva.mpg.de 